CRYSTALLOGRAPHIC COMMUNICATIONS

ISSN 2056-9890

Received 11 December 2017

Accepted 11 January 2018

Edited by D. Chopra, Indian Institute of Science Education and Research Bhopal, India

Keywords: crystal structure; $p$-phenylenediamine; adipic acid; mechanochemical synthesis; LAG; partial protonation; hydrogen bonding.

CCDC reference: 1816419

Supporting information: this article has supporting information at journals.iucr.org/e

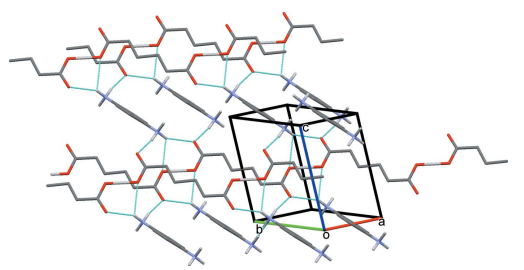

OPEN $\odot$ ACCESS

\section{Crystal structure of a new molecular salt: 4-aminobenzenaminium 5-carboxypentanoate}

\author{
Risha Mishra, ${ }^{a}$ Krishnan Rangan ${ }^{\mathrm{b}}$ and Raghavaiah Pallepogu ${ }^{\mathrm{a} *}$ \\ ${ }^{\mathbf{a}}$ Department of Chemistry, Dr. Harisingh Gour University, Sagar, MP 470 003, India, and ${ }^{\mathbf{b}}$ Birla Institute of Technology \& \\ Science, Pilani Hyderabad Campus, Jawahar Nagar, Shamirpeet Mandal, Ranga Reddy District, Secunderabad, Andhra \\ Pradesh 500 078, India. *Correspondence e-mail: rpallepogu@gmail.com
}

The asymmetric unit of the title molecular salt (systematic name: 4-aminoanilinium 5-carboxypentanoate), $\mathrm{C}_{6} \mathrm{H}_{9} \mathrm{~N}_{2}{ }^{+} \cdot \mathrm{C}_{6} \mathrm{H}_{9} \mathrm{O}_{4}{ }^{-}$, consists of half a 4-aminobenzenaminium cation (4-ABA) and half a 5-carboxypentanoate anion (5-CP); the other half of each ion is generated by inversion symmetry. Protonation of $p$-phenylenediamine (PPDA) leads to the formation of a 1:1 salt, but scrutiny of the crystal structure reveals that both of the amine groups of PPDA are partially protonated, with a half-occupied $\mathrm{H}$ atom. For the 5-CP anion, an $\mathrm{H}$ atom is positioned on an inversion center midway between two $\mathrm{O}$ atoms of inversion-related 5-CP ions. In the crystal, the 5-CP anions are linked by the $\mathrm{O}-\mathrm{H} \cdots \mathrm{O}$ hydrogen bond to form chains propagating along the [110] direction. The chains are linked via $\mathrm{N}-\mathrm{H} \cdots \mathrm{O}$ and $\mathrm{N}-\mathrm{H} \cdots \mathrm{N}$ hydrogen bonds involving the 4-ABA cations, forming a three-dimensional supramolecular framework. The title salt was also prepared by mechanochemical synthesis using liquid-assisted grinding (LAG). Its PXRD pattern matches that of the simulated pattern of the crystal structure of the title molecular salt.

\section{Chemical context}

$p$-Phenylenediamine (PPDA) has been widely used to synthesize hair dyes, engineering polymers and composites. The coordination chemistry of PPDA is well documented (Adams et al., 2011; Bourne \& Mangombo, 2004). Adipic acid (AA) is an industrial chemical used to manufacture nylon and is also used in many drugs and food additives (Rowe et al., 2009). A number of salts and co-crystals involving $p$-phenylenediamine have been reported (Thakuria et al., 2007; Delori et al., 2016), and adipic acid is also widely known as a coformer in co-crystal formation (Swinton Darious et al., 2016; Lemmerer et al., 2012; Lin et al., 2012; Matulková et al., 2014; Thanigaimani et al., 2012). A 2:1 salt of 4-aminoanilinium (PPDAH) and sebacate, and a 1:1 salt of PPDAH and dihydrogen trimesate have been reported recently (Delori et al., 2016). We have previously reported various salts of $o$-phenylenediamine with aromatic carboxylic acids (Mishra \& Pallepogu, 2018). Herein, we report on the synthesis and crystal structure of the 1:1 salt formed between $p$-phenylenediamine and adipic acid, (I).

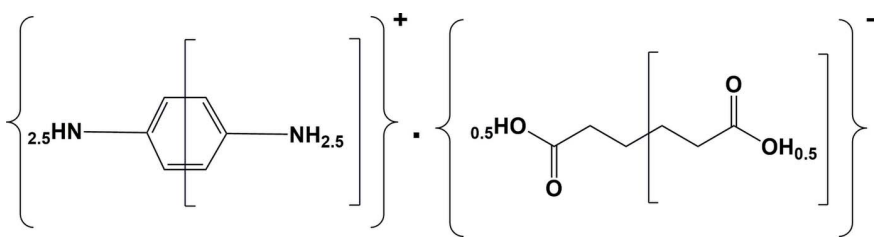




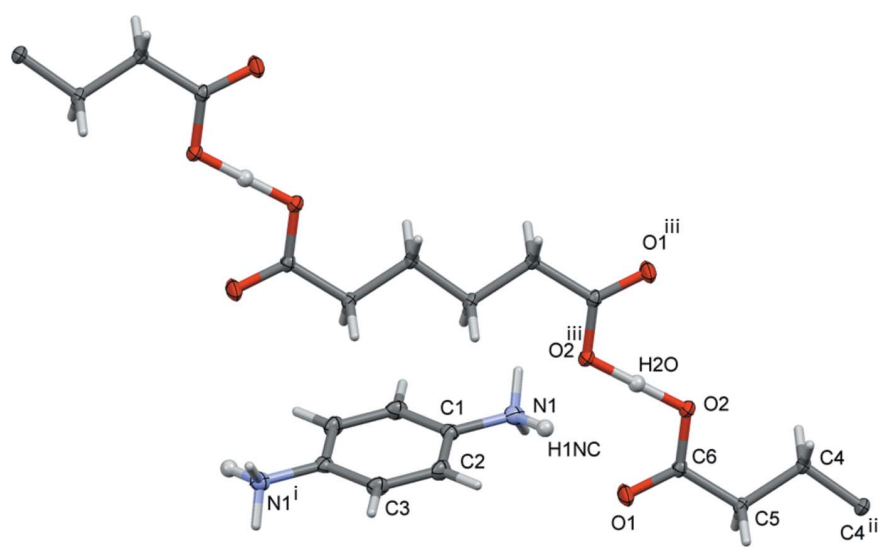

Figure 1

The molecular structure of the title molecular salt (I), with atom labelling for the asymmetric unit. Displacement ellipsoids are drawn at the $50 \%$ probability level. [Symmetry codes: (i) $-x+1,-y+2,-z+2$; (ii) $-x+2$, $-y,-z+1$; (iii) $-x+1,-y+1,-z+1]$.

\section{Structural commentary}

The asymmetric unit of the title salt (I), illustrated in Fig. 1, consists of half each of a 4-aminobenzenaminium cation (4ABA) and a 5-carboxypentanoate anion (5-CP); both ions (space group $P \overline{1}$ ) lie about inversion centres. Partial protonation $(50 \%)$ has occurred at atom N1 of the cation, resulting in the formation of a salt with the formula unit $\mathrm{C}_{6} \mathrm{H}_{9} \mathrm{O}_{4}{ }^{-} \cdot \mathrm{C}_{6} \mathrm{H}_{9} \mathrm{~N}_{2}{ }^{+}$. One of the two adipic acid $\mathrm{H}$ atoms binds to atom $\mathrm{N} 1$ with a site-occupancy factor (SOF) of 0.5 (for atom $\mathrm{H} 1 \mathrm{NC}$ ), thereby positioned at two sites (because of inversion symmetry) in the cation. The other acid $\mathrm{H}$ atom $(\mathrm{H} 2 \mathrm{O})$ is located on an inversion center and is therefore shared equally by two $\mathrm{O} 2$ atoms of inversion-related anions. The $\mathrm{C} 1-\mathrm{N} 1$ bond length [1.4361 (13) $\AA$ ] in the 4-ABA cation is longer than literature values for a non-protonated amine $\left(\mathrm{C}-\mathrm{NH}_{2}\right)$ group [cf. 1.418 (2) §; Czapik et al., 2010] and this can be attributed to the partial protonation with $\mathrm{SOF}=0.50$ at each site. In the 5-CP anion, the $\mathrm{C} 6=\mathrm{O} 1$ and $\mathrm{C} 6-\mathrm{O} 2$ bond lengths [1.2379 (12) and 1.2802 (11) А, respectively] are similar to the values reported for 2-methylimidazolium hydrogen adipate monohydrate [1.244 (2) and 1.264 (2) $\AA$, respectively; Meng et al., 2009] in which a carboxylic acid $\mathrm{H}$ atom is also statistically distributed between the two carboxy groups and a hydrogenbonded chain is formed. In (I), the position of this $\mathrm{H}$ atom $(\mathrm{H} 2 \mathrm{O})$ was located in a difference-Fourier map and found to be situated on an inversion centre $\left(\frac{1}{2}, \frac{1}{2}, \frac{1}{2}\right)$. It is positioned symmetrically between two $\mathrm{O} 2$ atoms of two inversion-related 5-CP ions, which accounts for the long $\mathrm{O}-\mathrm{H}$ bond length of $1.22 \AA$ (see Table 1 ). The $\mathrm{C} 4{ }^{\mathrm{ii}}-\mathrm{C} 4-\mathrm{C} 5-\mathrm{C} 6$ torsion angle of $-179.82(9)^{\circ}$ indicates that the carbon chain in the anion is fully extended [see Fig. 1 for symmetry code (ii)].

\section{Supramolecular features}

In general, adipic acid (AA) forms $R_{2}^{2}(8)$ homosynthons facilitated by strong $\mathrm{O}-\mathrm{H} \cdots \mathrm{O}$ interactions; however, it is known to form heterosynthons when co-crystallized with
Table 1

Hydrogen-bond geometry $\left(\AA,^{\circ}\right)$.

\begin{tabular}{lllll}
\hline$D-\mathrm{H} \cdots A$ & $D-\mathrm{H}$ & $\mathrm{H} \cdots A$ & $D \cdots A$ & $D-\mathrm{H} \cdots A$ \\
\hline $\mathrm{O} 2-\mathrm{H} 2 O \cdots \mathrm{O} 2^{\mathrm{i}}$ & 1.22 & 1.22 & $2.439(1)$ & 180 \\
$\mathrm{O} 2-\mathrm{H} 2 O \cdots 1^{\mathrm{i}}$ & 1.22 & 2.45 & $3.178(1)$ & 116 \\
$\mathrm{~N} 1-\mathrm{H} 1 N A \cdots \mathrm{O} 1^{\mathrm{ii}}$ & $0.91(2)$ & $1.97(2)$ & $2.871(1)$ & $171(1)$ \\
$\mathrm{N} 1-\mathrm{H} 1 N B \cdots \mathrm{O} 1$ & $0.90(2)$ & $2.24(2)$ & $3.060(1)$ & $152(1)$ \\
$\mathrm{N} 1-\mathrm{H} 1 N B \cdots \mathrm{O} 2^{\mathrm{i}}$ & $0.90(2)$ & $2.51(2)$ & $3.098(1)$ & $123(1)$ \\
$\mathrm{N} 1-\mathrm{H} 1 N C \cdots \mathrm{N} 1^{\mathrm{iii}}$ & $0.95(2)$ & $1.89(2)$ & $2.840(1)$ & $174(2)$ \\
\hline
\end{tabular}

Symmetry codes: (i) $\quad-x+1,-y+1,-z+1 ; \quad$ (ii) $\quad x-1, y, z$; amines (Lemmerer et al., 2010, 2012). In the crystal structure of (I), the formation of the $R_{2}^{2}(8)$ homosynthon is not favoured because of the inversion-related arrangement of the 5-CP anions, which forms a linear chain along the [1힐 direction (Fig. 2, Table 1) as a result of the sharing of the $\mathrm{H}$ atom $(\mathrm{H} 2 \mathrm{O})$ between the $\mathrm{O} 2$ atoms of inversion-related anions as discussed above; otherwise this could be supposed to be the contribution of a strong $\mathrm{O}-\mathrm{H} \cdots \mathrm{O}$ hydrogen bond. The crystal structure features interionic $\mathrm{N}-\mathrm{H} \cdots \mathrm{O}$ and $\mathrm{O}-\mathrm{H} \cdots \mathrm{O}$ hydrogen bonds between the anions and cations (Table 1, Fig. 3). One of the $\mathrm{H}$ atoms $(\mathrm{H} 1 B A)$ on $\mathrm{N} 1$ is a bifurcated hydrogen-bond donor and the carboxylate $\mathrm{O} 1$ atom of the anion acts as a triple acceptor, accepting $\mathrm{H}$ atoms from two different $\mathrm{NH}_{3}$ groups (H1NA and $\mathrm{H} 1 N B$ ), as illustrated in Fig. 3. The chains of the 5-CP anions are linked via the $\mathrm{N}-\mathrm{H} \cdots \mathrm{O}, \mathrm{O}-\mathrm{H} \cdots \mathrm{O}$ and $\mathrm{N}-$ $\mathrm{H} \cdots \mathrm{N}$ hydrogen bonds, forming a three-dimensional supramolecular framework (Table 1 and Fig. 4).

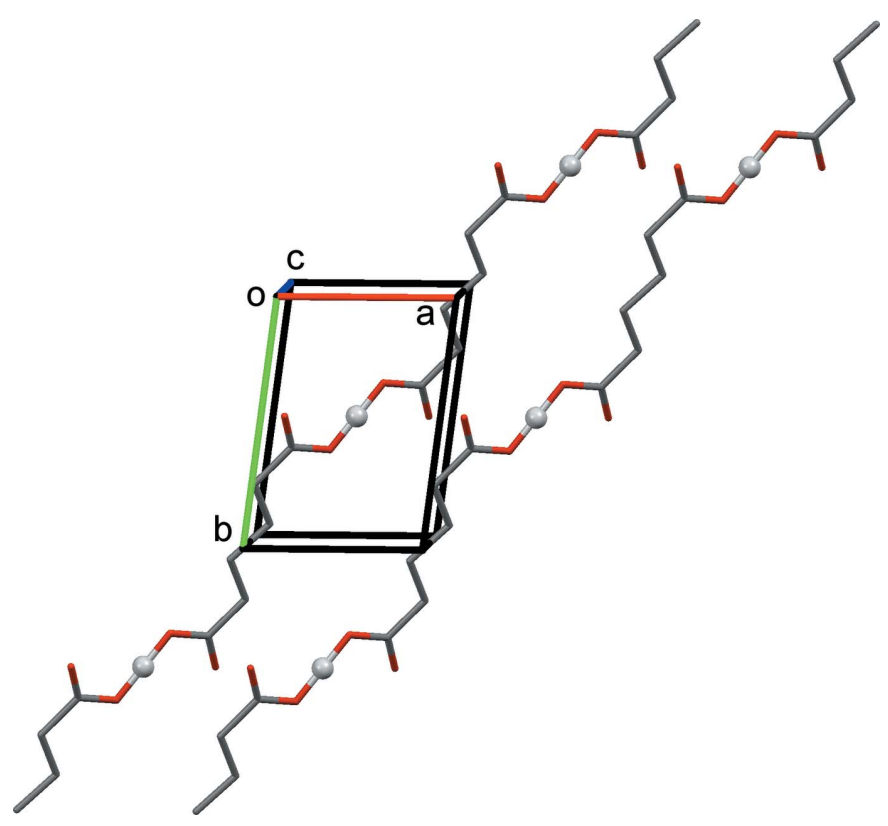

Figure 2

A view along the $c$ axis of the $\mathrm{O}-\mathrm{H} \cdots \mathrm{O}$ hydrogen-bonded chain of 5-CP anions (see Table 1). The $\mathrm{H}$ atoms ( $\mathrm{H} 2 \mathrm{O}$; shown as grey balls) are shared between $\mathrm{O} 2$ atoms of inversion-related anions. The $\mathrm{C}$-bound $\mathrm{H}$ atoms and the cations have been omitted. 


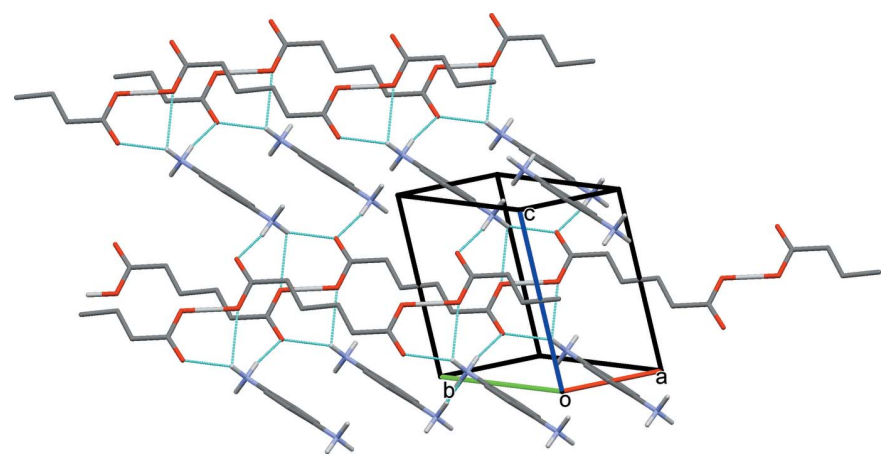

Figure 3

A partial view, normal to the $a b$ plane, of the crystal packing of the title molecular salt (I). Hydrogen bonds are shown as dashed lines (see Table 1), and C-bound $\mathrm{H}$ atoms have been omitted for clarity.

\section{Database survey}

A search of the Cambridge Structural Database (CSD, Version 5.38, update May 2017; Groom et al., 2016) for 4-aminoanilinium and 1,4-phenylenediammonium salts gave 70 hits. The crystal structure of $p$-phenylenediamine (PPDA) itself was first reported by Povetéva \& Zvonkova (1975). Perhaps the most relevant hit is for the structure of bis(4aminoanilinium) decanedioate (CSD refcode IPAPAS; Delori et al., 2016), one of the few salts formed with an aliphatic diacid. There are a number of structures reported of PPDA

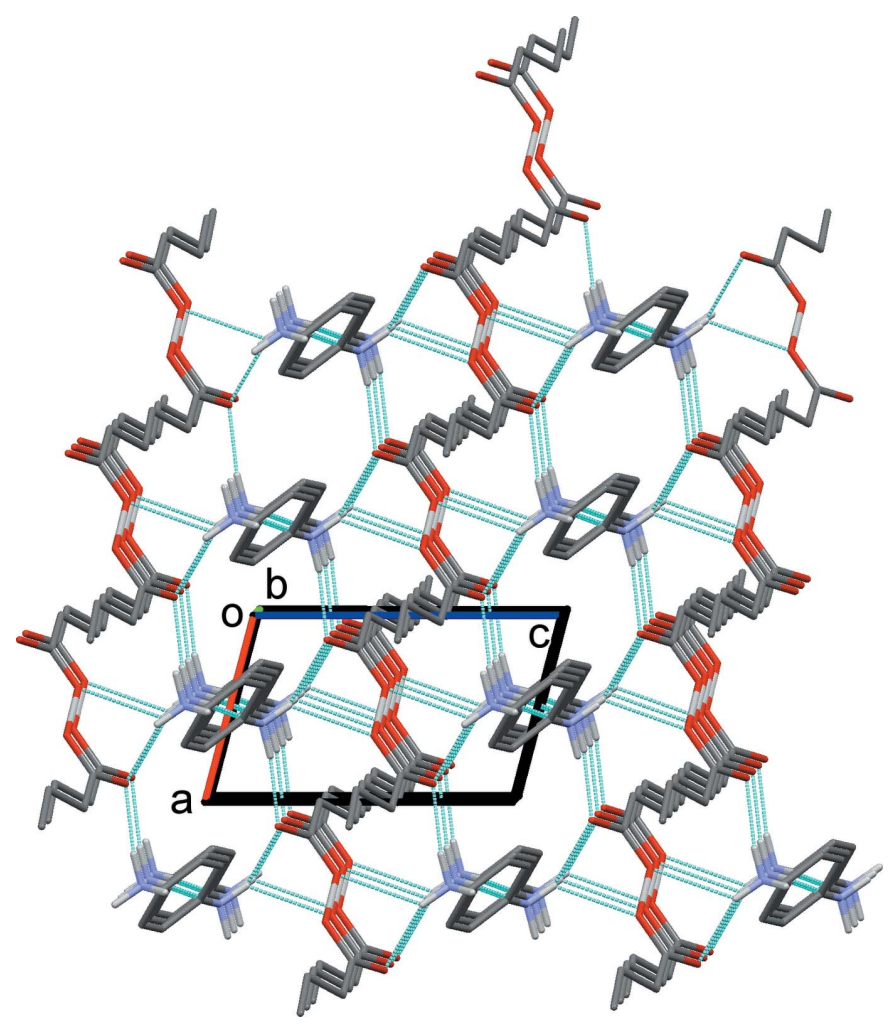

Figure 4

A view along the $b$ axis of the crystal packing of the title molecular salt (I), showing the three-dimensional supramolecular framework. Hydrogen bonds are shown as dashed lines (see Table 1), and $\mathrm{C}$-bound $\mathrm{H}$ atoms have been omitted for clarity. with mineral acids (Chandrasekaran, 1969; Marsh, 2009; Anderson et al., 2006), and co-crystals and salts of PPDA with organic acids (Thakuria et al., 2007; Delori et al., 2016). Some 1:1 co-crystals of PPDA and various diols (viz. 1,8-octane diol, 1,10-decane diol and 1,12-dodecane diol) have also been reported (Loehlin \& Okasako, 2007).

A search of the CSD for salts of adipic acid (AA) with different amines yielded 67 hits. One such structure of particular interest, viz. 2-methylimidazolium hydrogen adipate monohydrate, has been reported twice, once at room temperature (BOTTOU: Meng et al., 2009), where the same type of partial disorder is observed with the carboxylic acid $\mathrm{H}$ atom statistically distributed between the two carboxy groups and a hydrogen-bonded chain is formed. However, the lowtemperature analysis at $120 \mathrm{~K}$ using synchrotron radiation (BOTTOU01: Callear et al., 2010), describes the structure as bis(2-methylimidazolium) adipate adipic acid dihydrate. In the crystal, the adipate and adipic acid molecules also form a hydrogen-bonded chain. A second structure, tetrakis(cytosinium) dihydrogen bis(adipate), also exhibits the same type of disorder of the carboxylic acid $\mathrm{H}$ atom (OYEREQ; Das \& Baruah, 2011), and in the crystal it forms a hydrogen-bonded chain.

\section{Synthesis and crystallization}

The title molecular salt (I), was synthesized by mixing a $5 \mathrm{ml}$ methanolic solution of adipic acid (AA: $0.5 \mathrm{mmol}, 73 \mathrm{mg}$ ) and $3 \mathrm{ml}$ of an acetonitrile solution of $p$-phenylenediamine (PPDA: $0.5 \mathrm{mmol}, 54 \mathrm{mg}$ ). The reaction mixture was heated to $323 \mathrm{~K}$ with magnetic stirring for $c a 30 \mathrm{~min}$, and then filtered and allowed to evaporate slowly at room temperature. Purple block-like crystals of (I) were obtained after 5 d (m.p. $438 \mathrm{~K}$ ). FTIR (KBr pellet, $\mathrm{cm}^{-1)}$ : v 3337, 3180, 2946, 2383, 1706, 1515, $1255,821,743,501,475$.

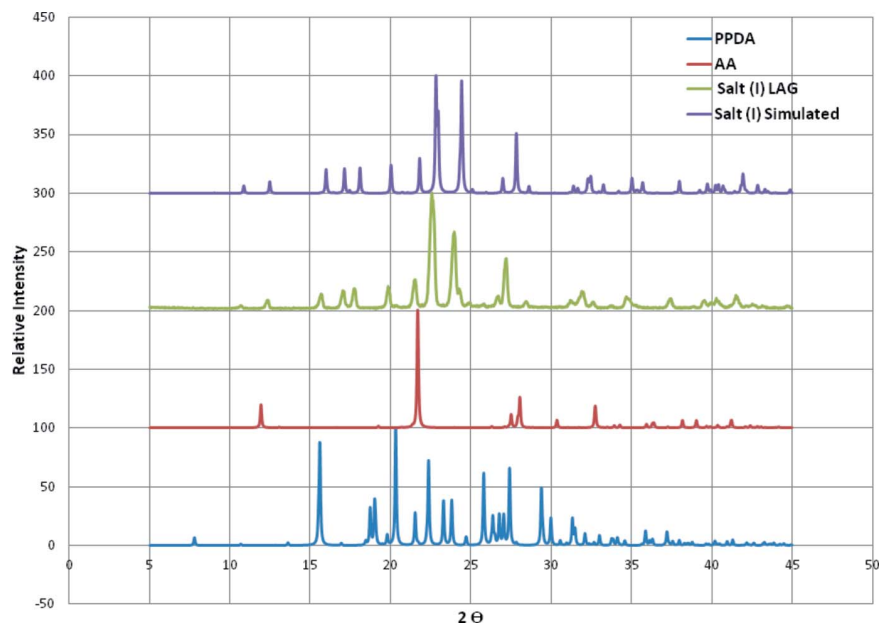

Figure 5

The PXRD pattern obtained from the product of the LAG experiment, and the simulated PXRD pattern of the crystal structure of the title molecular salt. The PXRD patterns of the reactants used for the cocrystallization and LAG syntheses are also shown. 
Table 2

Experimental details.

\begin{tabular}{|c|c|}
\hline \multicolumn{2}{|l|}{ Crystal data } \\
\hline Chemical formula & $\mathrm{C}_{6} \mathrm{H}_{9} \mathrm{~N}_{2}{ }^{+} \cdot \mathrm{C}_{6} \mathrm{H}_{9} \mathrm{O}_{4}{ }^{-}$ \\
\hline$M_{\mathrm{r}}$ & 254.28 \\
\hline Crystal system, space group & Triclinic, $P \overline{1}$ \\
\hline Temperature (K) & 100 \\
\hline$a, b, c(\AA)$ & $5.2918(3), 7.1666(4), 8.4205(7)$ \\
\hline$\alpha, \beta, \gamma\left(^{\circ}\right)$ & $92.069(6), 104.165(6), 97.172(5)$ \\
\hline$V\left(\AA^{3}\right)$ & $306.47(4)$ \\
\hline$Z$ & 1 \\
\hline Radiation type & Мо $K \alpha$ \\
\hline$\mu\left(\mathrm{mm}^{-1}\right)$ & 0.10 \\
\hline Crystal size (mm) & $0.42 \times 0.38 \times 0.32$ \\
\hline \multicolumn{2}{|l|}{ Data collection } \\
\hline Diffractometer & $\begin{array}{l}\text { Rigaku Oxford Diffraction } \\
\text { XtaLAB Pro: Kappa dual offset/ } \\
\text { far }\end{array}$ \\
\hline Absorption correction & $\begin{array}{l}\text { Multi-scan (CrysAlis PRO; Rigaku } \\
\text { OD, 2015) }\end{array}$ \\
\hline$T_{\min }, T_{\max }$ & $0.924,1.000$ \\
\hline $\begin{array}{l}\text { No. of measured, independent and } \\
\text { observed }[I>2 \sigma(I)] \text { reflections }\end{array}$ & $3776,1416,1341$ \\
\hline$R_{\text {int }}$ & 0.015 \\
\hline$(\sin \theta / \lambda)_{\max }\left(\AA^{-1}\right)$ & 0.685 \\
\hline \multicolumn{2}{|l|}{ Refinement } \\
\hline$R\left[F^{2}>2 \sigma\left(F^{2}\right)\right], w R\left(F^{2}\right), S$ & $0.034,0.092,1.08$ \\
\hline No. of reflections & 1416 \\
\hline No. of parameters & 96 \\
\hline H-atom treatment & $\begin{array}{l}\mathrm{H} \text { atoms treated by a mixture of } \\
\text { independent and constrained } \\
\text { refinement }\end{array}$ \\
\hline$\Delta \rho_{\max }, \Delta \rho_{\min }\left(\mathrm{e} \AA^{-3}\right)$ & $0.39,-0.22$ \\
\hline
\end{tabular}

Computer programs: CrysAlis PRO (Rigaku OD, 2015), SHELXS97 (Sheldrick, 2008), SHELXL2016/6 (Sheldrick, 2015), OLEX2 (Dolomanov et al., 2009), Mercury (Macrae et al., 2008), PLATON (Spek, 2009) and publCIF (Westrip (2010).

The title compound was also synthesized by liquid-assisted grinding (LAG). For this mechanochemical synthesis, equimolar amounts of AA (1 mmol, $146 \mathrm{mg})$ and PPDA (1 mmol, $108 \mathrm{mg}$ ) were ground for $20 \mathrm{~min}$. in a mortar and pestle using 3 to 4 drops of acetonitrile. The powdered sample was collected for PXRD and the resultant pattern was scrutinized for new peaks, as evidence for the formation of the title molecular salt (I), by comparing this pattern with the simulated pattern obtained from the CIF file of salt (I). The PXRD pattern of the compound obtained from the LAG experiment matches the simulated pattern obtained for (I), formed by co-crystallization (Fig. 5).

\section{Refinement}

Crystal data, data collection and structure refinement details are summarized in Table 2. C-bound $\mathrm{H}$ atoms were placed in calculated positions and refined using a riding-model approximation: $0.95-09.99 \AA$ with $U_{\text {iso }}(\mathrm{H})=1.2 U_{\text {eq }}(\mathrm{C})$. The ammonium and carboxyl $\mathrm{H}$ atoms were located in differenceFourier maps and were freely refined. The $\mathrm{H}$ atom $(\mathrm{H} 1 N C)$ bound to N1 of the 4-ABA cation, with an occupancy factor of 0.5 , is positioned at two sites of the cation due to inversion symmetry, giving rise to a monoprotonated species. The carboxylic acid $\mathrm{H}$ atom $(\mathrm{H} 2 \mathrm{O})$ is positioned symmetrically between the two $\mathrm{O} 2$ atoms of inversion-related 5-CP ions $(\mathrm{H}-\mathrm{O}=1.22 \AA)$. This $\mathrm{H}$ atom $(\mathrm{H} 2 \mathrm{O})$ is located on an inversion center $\left(\frac{1}{2}, \frac{1}{2}, \frac{1}{2}\right)$ with an occupancy factor of 0.5 , and hence gives rise to a mono-deprotonated species.

\section{Acknowledgements}

The authors thank Professor B. R. Srinivasan, Goa University and Dr N. Jagadeesh Babu, IICT, Hyderabad for useful discussions.

\section{Funding information}

The authors thank the DST PURSE for financial assistance in procuring instrumental facilities through the SIC. Dr. Harisingh Gour University, the UGC, New Delhi (UGC Start-up grant to RP) and the DST, New Delhi (SERB grant SB/ EMEQ-287/2014 to RP) are gratefully acknowledged for financial support.

\section{References}

Adams, C. J., Haddow, M. F., Lusi, M. \& Orpen, A. G. (2011). CrystEngComm, 13, 4324-4331.

Anderson, K. M., Goeta, A. E., Hancock, K. S. B. \& Steed, J. W. (2006). Chem. Commun. pp. 2138-2140.

Bourne, S. A. \& Mangombo, Z. (2004). CrystEngComm, 6, 437-442.

Callear, S. K., Hursthouse, M. B. \& Threlfall, T. L. (2010). CrystEngComm, 12, 898-908.

Chandrasekaran, R. (1969). Acta Cryst. B25, 369-374.

Czapik, A., Konowalska, H. \& Gdaniec, M. (2010). Acta Cryst. C66, o128-o132.

Das, B. \& Baruah, J. B. (2011). J. Mol. Struct. 1001, 134-138.

Delori, A., Urquhart, A. J. \& Oswald, I. D. H. (2016). CrystEngComm, 18, 5360-5364.

Dolomanov, O. V., Bourhis, L. J., Gildea, R. J., Howard, J. A. K. \& Puschmann, H. (2009). J. Appl. Cryst. 42, 339-341.

Groom, C. R., Bruno, I. J., Lightfoot, M. P. \& Ward, S. C. (2016). Acta Cryst. B72, 171-179.

Lemmerer, A., Bernstein, J. \& Kahlenberg, V. (2010). CrystEngComm, 12, 2856-2864.

Lemmerer, A., Bernstein, J. \& Kahlenberg, V. (2012). Acta Cryst. E68, o190.

Lin, S., Jia, R., Gao, F. \& Zhou, X. (2012). Acta Cryst. E68, o3457.

Loehlin, J. H. \& Okasako, E. L. N. (2007). Acta Cryst. B63, 132-141.

Macrae, C. F., Bruno, I. J., Chisholm, J. A., Edgington, P. R., McCabe, P., Pidcock, E., Rodriguez-Monge, L., Taylor, R., van de Streek, J. \& Wood, P. A. (2008). J. Appl. Cryst. 41, 466-470.

Marsh, R. E. (2009). Acta Cryst. B65, 782-783.

Matulková, I., Císařová, I., Němec, I. \& Fábry, J. (2014). Acta Cryst. C70, 927-933.

Meng, X.-G., Cheng, C.-X. \& Yan, G. (2009). Acta Cryst. C65, o217o221.

Mishra, R. \& Pallepogu, R. (2018). Acta Cryst. B74, 32-41.

Povetéva, Z. P. \& Zvonkova, Z. V. (1975). Kristallografiya, 20, 69.

Rigaku OD (2015). CrysAlis PRO. Rigaku Oxford Diffraction Ltd, Yarnton, England.

Rowe, R. C., Sheskey, P. J. \& Quinn, M. E. (2009). Adipic Acid. In Handbook of Pharmaceutical Excipients, 6th ed., pp. 11-12. London: Pharmaceutical Press.

Sheldrick, G. M. (2008). Acta Cryst. A64, 112-122.

Sheldrick, G. M. (2015). Acta Cryst. C71, 3-8.

Spek, A. L. (2009). Acta Cryst. D65, 148-155.

Swinton Darious, R., Thomas Muthiah, P. \& Perdih, F. (2016). Acta Cryst. E72, 805-808. 
Thakuria, H., Borah, B. M., Pramanik, A. \& Das, G. (2007). J. Chem. Crystallogr. 37, 807-816.
Thanigaimani, K., Razak, I. A., Arshad, S., Jagatheesan, R. \& Santhanaraj, K. J. (2012). Acta Cryst. E68, o2938-o2939. Westrip, S. P. (2010). J. Appl. Cryst. 43, 920-925. 


\section{supporting information}

Acta Cryst. (2018). E74, 201-205 [https://doi.org/10.1107/S2056989018000737]

\section{Crystal structure of a new molecular salt: 4-aminobenzenaminium 5-carboxy-} pentanoate

\section{Risha Mishra, Krishnan Rangan and Raghavaiah Pallepogu}

Computing details

Data collection: CrysAlis PRO (Rigaku OD, 2015); cell refinement: CrysAlis PRO (Rigaku OD, 2015); data reduction: CrysAlis PRO (Rigaku OD, 2015); program(s) used to solve structure: SHELXS97 (Sheldrick, 2008); program(s) used to refine structure: SHELXL2016/6 (Sheldrick, 2015); molecular graphics: OLEX2 (Dolomanov et al., 2009) and Mercury (Macrae et al., 2008); software used to prepare material for publication: SHELXL2016/6 (Sheldrick, 2015), OLEX2 (Dolomanov et al., 2009), PLATON (Spek, 2009) and publCIF (Westrip (2010).

4-Aminoanilinium 5-carboxypentanoate

Crystal data

$\mathrm{C}_{6} \mathrm{H}_{9} \mathrm{~N}_{2}+\mathrm{C}_{6} \mathrm{H}_{9} \mathrm{O}_{4}^{-}$

$M_{r}=254.28$

Triclinic, $P \overline{1}$

$a=5.2918(3) \AA$

$b=7.1666(4) \AA$

$c=8.4205(7) \AA$

$\alpha=92.069(6)^{\circ}$

$\beta=104.165(6)^{\circ}$

$\gamma=97.172(5)^{\circ}$

$V=306.47(4) \AA^{3}$

\section{Data collection}

Rigaku Oxford Diffraction XtaLAB Pro: Kappa dual offset/far

diffractometer

Radiation source: fine-focus sealed X-ray tube, Enhance (Mo) X-ray Source

Graphite monochromator

$\omega$ scans

Absorption correction: multi-scan

(CrysAlis PRO; Rigaku OD, 2015)

\section{Refinement}

Refinement on $F^{2}$

Least-squares matrix: full

$R\left[F^{2}>2 \sigma\left(F^{2}\right)\right]=0.034$

$w R\left(F^{2}\right)=0.092$

$S=1.08$

1416 reflections
$Z=1$

$F(000)=136$

$D_{\mathrm{x}}=1.378 \mathrm{Mg} \mathrm{m}^{-3}$

Mo $K \alpha$ radiation, $\lambda=0.71073 \AA$

Cell parameters from 5347 reflections

$\theta=5.2-29.2^{\circ}$

$\mu=0.10 \mathrm{~mm}^{-1}$

$T=100 \mathrm{~K}$

Block, purple

$0.42 \times 0.38 \times 0.32 \mathrm{~mm}$

$T_{\min }=0.924, T_{\max }=1.000$

3776 measured reflections

1416 independent reflections

1341 reflections with $I>2 \sigma(I)$

$R_{\text {int }}=0.015$

$\theta_{\max }=29.1^{\circ}, \theta_{\min }=5.0^{\circ}$

$h=-5 \rightarrow 7$

$k=-9 \rightarrow 8$

$l=-11 \rightarrow 10$

96 parameters

0 restraints

Primary atom site location: structure-invariant direct methods

Secondary atom site location: difference Fourier map 
Hydrogen site location: mixed

$\mathrm{H}$ atoms treated by a mixture of independent and constrained refinement

$w=1 /\left[\sigma^{2}\left(F_{\mathrm{o}}^{2}\right)+(0.0483 P)^{2}+0.0998 P\right]$

where $P=\left(F_{\mathrm{o}}^{2}+2 F_{\mathrm{c}}{ }^{2}\right) / 3$

$(\Delta / \sigma)_{\max }<0.001$

\author{
$\Delta \rho_{\max }=0.39$ e $\AA^{-3}$ \\ $\Delta \rho_{\min }=-0.22 \mathrm{e} \AA^{-3}$ \\ Extinction correction: (SHELXL-2016/6; \\ Sheldrick, 2015), \\ $\mathrm{Fc}^{*}=\mathrm{kFc}\left[1+0.001 \times \mathrm{Fc}^{2} \lambda^{3} / \sin (2 \theta)\right]^{-1 / 4}$ \\ Extinction coefficient: 0.15 (2)
}

\section{Special details}

Geometry. All esds (except the esd in the dihedral angle between two 1.s. planes) are estimated using the full covariance matrix. The cell esds are taken into account individually in the estimation of esds in distances, angles and torsion angles; correlations between esds in cell parameters are only used when they are defined by crystal symmetry. An approximate (isotropic) treatment of cell esds is used for estimating esds involving 1.s. planes.

Fractional atomic coordinates and isotropic or equivalent isotropic displacement parameters $\left(\AA^{2}\right)$

\begin{tabular}{llllll}
\hline & $x$ & $y$ & $z$ & $U_{\text {iso }} * / U_{\text {eq }}$ & Occ. $(<1)$ \\
\hline O1 & $0.88613(16)$ & $0.51078(11)$ & $0.73311(10)$ & $0.0284(2)$ & \\
O2 & $0.62365(13)$ & $0.36690(9)$ & $0.50333(8)$ & $0.0159(2)$ & \\
H2O & 0.500000 & 0.500000 & 0.500000 & $0.079(10)^{*}$ & \\
C4 & $0.90322(17)$ & $0.07097(12)$ & $0.49487(11)$ & $0.0140(2)$ & \\
H4A & 0.867169 & 0.119848 & 0.384244 & $0.017^{*}$ & \\
H4B & 0.735161 & 0.007357 & 0.511087 & $0.017^{*}$ & \\
C5 & $1.01023(17)$ & $0.23441(12)$ & $0.62353(11)$ & $0.0127(2)$ & \\
H5A & 1.048177 & 0.183438 & 0.733310 & $0.015^{*}$ & \\
H5B & 1.178973 & 0.295883 & 0.606644 & $0.015^{*}$ & \\
C6 & $0.82994(17)$ & $0.38253(12)$ & $0.62270(11)$ & $0.0122(2)$ & \\
N1 & $0.43897(17)$ & $0.62290(12)$ & $0.87167(10)$ & $0.0177(2)$ & \\
H1NA & $0.268(3)$ & $0.582(2)$ & $0.8186(19)$ & $0.033(4)^{*}$ & \\
H1NB & $0.538(3)$ & $0.608(2)$ & $0.800(2)$ & $0.036(4)^{*}$ & \\
H1NC & $0.470(5)$ & $0.534(3)$ & $0.953(3)$ & $0.013(6)^{*}$ & \\
C1 & $0.47080(18)$ & $0.81542(13)$ & $0.93517(11)$ & $0.0147(2)$ & \\
C2 & $0.65701(19)$ & $0.95024(15)$ & $0.89941(12)$ & $0.0180(2)$ & \\
H2 & 0.764255 & 0.916272 & 0.830590 & $0.022^{*}$ & \\
C3 & $0.68658(19)$ & $1.13477(14)$ & $0.96421(12)$ & $0.0179(2)$ & \\
H3 & 0.814280 & 1.227114 & 0.939883 & $0.021^{*}$ & \\
& & & &
\end{tabular}

Atomic displacement parameters $\left(\AA^{2}\right)$

\begin{tabular}{lllllll}
\hline & $U^{11}$ & $U^{22}$ & $U^{\beta 3}$ & $U^{12}$ & $U^{13}$ & $U^{23}$ \\
\hline O1 & $0.0309(4)$ & $0.0199(4)$ & $0.0270(4)$ & $0.0138(3)$ & $-0.0099(3)$ & $-0.0120(3)$ \\
O2 & $0.0149(4)$ & $0.0149(3)$ & $0.0169(4)$ & $0.0069(3)$ & $0.0000(3)$ & $-0.0023(3)$ \\
C4 & $0.0124(4)$ & $0.0124(4)$ & $0.0173(5)$ & $0.0051(3)$ & $0.0023(3)$ & $-0.0011(3)$ \\
C5 & $0.0108(4)$ & $0.0119(4)$ & $0.0154(4)$ & $0.0034(3)$ & $0.0027(3)$ & $0.0006(3)$ \\
C6 & $0.0131(4)$ & $0.0101(4)$ & $0.0144(4)$ & $0.0023(3)$ & $0.0049(3)$ & $0.0015(3)$ \\
N1 & $0.0164(4)$ & $0.0225(4)$ & $0.0144(4)$ & $0.0030(3)$ & $0.0040(3)$ & $0.0012(3)$ \\
C1 & $0.0137(4)$ & $0.0187(5)$ & $0.0107(4)$ & $0.0033(3)$ & $0.0009(3)$ & $0.0006(3)$ \\
C2 & $0.0160(4)$ & $0.0246(5)$ & $0.0154(4)$ & $0.0041(4)$ & $0.0070(3)$ & $0.0008(4)$ \\
C3 & $0.0149(4)$ & $0.0223(5)$ & $0.0172(5)$ & $0.0003(4)$ & $0.0064(4)$ & $0.0023(4)$ \\
\hline
\end{tabular}


Geometric parameters $\left(\AA,{ }^{\circ}\right)$

\begin{tabular}{|c|c|c|c|}
\hline $\mathrm{O} 1-\mathrm{C} 6$ & $1.2379(12)$ & $\mathrm{N} 1-\mathrm{C} 1$ & $1.4361(13)$ \\
\hline $\mathrm{O} 2-\mathrm{C} 6$ & $1.2802(11)$ & $\mathrm{N} 1-\mathrm{H} 1 \mathrm{NA}$ & $0.914(17)$ \\
\hline $\mathrm{O} 2-\mathrm{H} 2 \mathrm{O}$ & $1.2197(6)$ & $\mathrm{N} 1-\mathrm{H} 1 \mathrm{NB}$ & $0.906(17)$ \\
\hline $\mathrm{C} 4-\mathrm{C} 5$ & $1.5195(12)$ & $\mathrm{N} 1-\mathrm{H} 1 \mathrm{NC}$ & $0.95(2)$ \\
\hline $\mathrm{C} 4-\mathrm{C}^{\mathrm{i}}$ & $1.5213(16)$ & $\mathrm{C} 1-\mathrm{C} 2$ & $1.3870(14)$ \\
\hline $\mathrm{C} 4-\mathrm{H} 4 \mathrm{~A}$ & 0.9900 & $\mathrm{C} 1-\mathrm{C} 3^{\mathrm{ii}}$ & $1.3916(13)$ \\
\hline $\mathrm{C} 4-\mathrm{H} 4 \mathrm{~B}$ & 0.9900 & $\mathrm{C} 2-\mathrm{C} 3$ & $1.3876(14)$ \\
\hline $\mathrm{C} 5-\mathrm{C} 6$ & $1.5123(12)$ & $\mathrm{C} 2-\mathrm{H} 2$ & 0.9500 \\
\hline $\mathrm{C} 5-\mathrm{H} 5 \mathrm{~A}$ & 0.9900 & $\mathrm{C} 3-\mathrm{H} 3$ & 0.9500 \\
\hline C5-H5B & 0.9900 & & \\
\hline $\mathrm{C} 6-\mathrm{O} 2-\mathrm{H} 2 \mathrm{O}$ & $113.50(6)$ & $\mathrm{C} 1-\mathrm{N} 1-\mathrm{H} 1 \mathrm{NA}$ & $111.1(9)$ \\
\hline $\mathrm{C} 5-\mathrm{C} 4-\mathrm{C}^{\mathrm{i}}$ & $111.39(9)$ & $\mathrm{C} 1-\mathrm{N} 1-\mathrm{H} 1 \mathrm{NB}$ & $111.9(10)$ \\
\hline $\mathrm{C} 5-\mathrm{C} 4-\mathrm{H} 4 \mathrm{~A}$ & 109.3 & $\mathrm{H} 1 \mathrm{NA}-\mathrm{N} 1-\mathrm{H} 1 \mathrm{NB}$ & $107.8(14)$ \\
\hline $\mathrm{C} 4-\mathrm{C} 4-\mathrm{H} 4 \mathrm{~A}$ & 109.3 & $\mathrm{C} 1-\mathrm{N} 1-\mathrm{H} 1 \mathrm{NC}$ & $114.7(15)$ \\
\hline $\mathrm{C} 5-\mathrm{C} 4-\mathrm{H} 4 \mathrm{~B}$ & 109.3 & $\mathrm{H} 1 \mathrm{NA}-\mathrm{N} 1-\mathrm{H} 1 \mathrm{NC}$ & $101.0(18)$ \\
\hline $\mathrm{C} 4-\mathrm{C} 4-\mathrm{H} 4 \mathrm{~B}$ & 109.3 & $\mathrm{H} 1 \mathrm{NB}-\mathrm{N} 1-\mathrm{H} 1 \mathrm{NC}$ & $109.6(18)$ \\
\hline $\mathrm{H} 4 \mathrm{~A}-\mathrm{C} 4-\mathrm{H} 4 \mathrm{~B}$ & 108.0 & $\mathrm{C} 2-\mathrm{C} 1-\mathrm{C} 3^{\mathrm{ii}}$ & $120.02(9)$ \\
\hline $\mathrm{C} 6-\mathrm{C} 5-\mathrm{C} 4$ & $115.04(8)$ & $\mathrm{C} 2-\mathrm{C} 1-\mathrm{N} 1$ & $121.06(8)$ \\
\hline $\mathrm{C} 6-\mathrm{C} 5-\mathrm{H} 5 \mathrm{~A}$ & 108.5 & $\mathrm{C} 3^{\mathrm{ii}}-\mathrm{C} 1-\mathrm{N} 1$ & $118.91(9)$ \\
\hline $\mathrm{C} 4-\mathrm{C} 5-\mathrm{H} 5 \mathrm{~A}$ & 108.5 & $\mathrm{C} 1-\mathrm{C} 2-\mathrm{C} 3$ & $119.97(9)$ \\
\hline $\mathrm{C} 6-\mathrm{C} 5-\mathrm{H} 5 \mathrm{~B}$ & 108.5 & $\mathrm{C} 1-\mathrm{C} 2-\mathrm{H} 2$ & 120.0 \\
\hline $\mathrm{C} 4-\mathrm{C} 5-\mathrm{H} 5 \mathrm{~B}$ & 108.5 & $\mathrm{C} 3-\mathrm{C} 2-\mathrm{H} 2$ & 120.0 \\
\hline $\mathrm{H} 5 \mathrm{~A}-\mathrm{C} 5-\mathrm{H} 5 \mathrm{~B}$ & 107.5 & $\mathrm{C} 2-\mathrm{C} 3-\mathrm{C} 1^{\mathrm{ii}}$ & $120.01(9)$ \\
\hline $\mathrm{O} 1-\mathrm{C} 6-\mathrm{O} 2$ & $123.47(8)$ & $\mathrm{C} 2-\mathrm{C} 3-\mathrm{H} 3$ & 120.0 \\
\hline $\mathrm{O} 1-\mathrm{C} 6-\mathrm{C} 5$ & $120.06(8)$ & $\mathrm{C} 1^{\mathrm{ii}}-\mathrm{C} 3-\mathrm{H} 3$ & 120.0 \\
\hline $\mathrm{O} 2-\mathrm{C} 6-\mathrm{C} 5$ & $116.47(8)$ & & \\
\hline $\mathrm{C} 4-\mathrm{C} 4-\mathrm{C} 5-\mathrm{C} 6$ & $-179.82(9)$ & $\mathrm{C} 3^{\mathrm{ii}}-\mathrm{C} 1-\mathrm{C} 2-\mathrm{C} 3$ & $0.09(16)$ \\
\hline $\mathrm{C} 4-\mathrm{C} 5-\mathrm{C} 6-\mathrm{O} 1$ & $172.41(9)$ & $\mathrm{N} 1-\mathrm{C} 1-\mathrm{C} 2-\mathrm{C} 3$ & $-179.06(9)$ \\
\hline $\mathrm{C} 4-\mathrm{C} 5-\mathrm{C} 6-\mathrm{O} 2$ & $-8.04(12)$ & $\mathrm{C} 1-\mathrm{C} 2-\mathrm{C} 3-\mathrm{C} 1^{\mathrm{ii}}$ & $-0.10(16)$ \\
\hline
\end{tabular}

Symmetry codes: (i) $-x+2,-y,-z+1$; (ii) $-x+1,-y+2,-z+2$.

Hydrogen-bond geometry $\left(A,{ }^{\circ}\right)$

\begin{tabular}{lllll}
\hline$D-\mathrm{H} \cdots A$ & $D-\mathrm{H}$ & $\mathrm{H} \cdots A$ & $D \cdots A$ & $D-\mathrm{H} \cdots A$ \\
\hline $\mathrm{O} 2-\mathrm{H} 2 O \cdots \mathrm{O} 2^{\mathrm{iii}}$ & 1.22 & 1.22 & $2.439(1)$ & 180 \\
$\mathrm{O} 2-\mathrm{H} 2 O \cdots \mathrm{O} 1^{\mathrm{iii}}$ & 1.22 & 2.45 & $3.178(1)$ & 116 \\
$\mathrm{~N} 1-\mathrm{H} 1 N A \cdots \mathrm{O} 1^{\text {iv }}$ & $0.91(2)$ & $1.97(2)$ & $2.871(1)$ & $171(1)$ \\
$\mathrm{N} 1-\mathrm{H} 1 N B \cdots \mathrm{O} 1$ & $0.90(2)$ & $2.24(2)$ & $3.060(1)$ & $152(1)$ \\
$\mathrm{N} 1-\mathrm{H} 1 N B \cdots \mathrm{O} 2^{i i i}$ & $0.90(2)$ & $2.51(2)$ & $3.098(1)$ & $123(1)$ \\
$\mathrm{N} 1-\mathrm{H} 1 N C \cdots \mathrm{N} 1^{\mathrm{i}}$ & $0.95(2)$ & $1.89(2)$ & $2.840(1)$ & $174(2)$
\end{tabular}

Symmetry codes: (iii) $-x+1,-y+1,-z+1$; (iv) $x-1, y, z$; (v) $-x+1,-y+1,-z+2$. 